Olmedilla-Alonso B, Estévez-Santiago R. Fruit and vegetable intake and the macular pigment optical density. Cap. 32, en: Handbook of Nutrition, Diet and the Eye. 2nd ed. Eds: Preddy V.R, Watson R.R. Academic Press (AP), Elsevier Inc. ISBN: 978-0-12-815245-4. Pp. 529- 549. June, 2019

\title{
Fruit and vegetable intake and the macular pigment optical density
}

\author{
Begoña Olmedilla-Alonso ${ }^{1}$, Rocío Estévez-Santiago ${ }^{2}$
}

\begin{abstract}
${ }^{1}$ Department of Metabolism and Nutrition. Institute of Food Science, Technology and Nutrition (ICTAN-CSIC). C/ José Antonio Novais, 10. 28040-Madrid (Spain).

Phone: +34- 91549 2300, e-mail: BOlmedilla@ictan.csic.es;

2 Área de Ciencia Gastronómica. Facultad de Ciencias Jurídicas y Empresariales. Universidad Francisco de Vitoria (UFV). Carretera Pozuelo-Majadahonda km. 1,800 28223 Pozuelo de Alarcón-Madrid (Spain). Phone: +34 91351 0303, e-mail: rocio.estevez@ufv.es;
\end{abstract}

Corresponding Author: Begoña Olmedilla-Alonso

\begin{abstract}
Fruit and vegetables supply nutrients and other bioactive compounds, including lutein and zeaxanthin, to human diet. Macular pigment (MP) is composed of lutein and zeaxanthin, from dietary origin, and mesozeaxanthin. MP has been studied in relation with ocular health (visual function and risk of chronic eye diseases). This chapter focuses on the relationship between lutein and zeaxanthin intake from overall diet or from fruit
\end{abstract}


and vegetables with the MPOD, and on the factors influencing the comparison of results across studies (i.e. methodological, subject- and food-related). Public health dietary recommendations encourage increased fruit and vegetable consumption, and certain scientific organism highlight the benefits of green-colored foods. However, the amount of dietary lutein and zeaxanthin is not the only determinant of increasing MPOD; in fact, their bioavailability from food matrixes is crucial. Several studies suggest that foods of red/orange color (mainly fruits) are better sources /contributors than those of green color.

Key Words: fruit, vegetables, dietary intake, macular, pigment, lutein, zeaxanthin, carotenoids.

\section{Introduction}

Fruit and vegetables supply nutrients and other bioactive compounds (i.e. lutein and zeaxanthin) to human dietary intake. The macular pigment (MP) is composed of lutein and zeaxanthin (from dietary origin, mainly supplied by fruit, vegetables, eggs and egg products) and mesozeaxanthin. Macular pigment is often positively associated with dietary and serum lutein and zeaxanthin concentrations and it has been studied in relation with ocular health (visual function and risk of chronic eye diseases). This chapter reviews the literature on the relationship between the dietary intake of lutein and zeaxanthin, focusing on that provided by fruit and vegetable and the MP in healthy and diseased people, as well as on aspects that may influence the comparison of results across studies, including those related to the assessment methods and those related to the bioavailability of lutein and zeaxanthin. 


\section{Fruit and vegetable intake - an indicator of diet quality and food sources of nutrients and bioactive compounds}

Fruit and vegetables supply many nutrients and other bioactive compounds to human dietary intake and, a higher intake of these food groups is considered an indicator of diet quality and is associated with a lower risk of several noncommunicable diseases

${ }^{1,2}$. On the other hand, diet and some food components are identified as risk factors in the origin and development of several chronic diseases, some of them ocular diseases ${ }^{3}$. Many of those compounds, acting alone or in combination, could be responsible for these beneficial associations ${ }^{4}$, which include macular pigments, lutein and zeaxanthin, as well as other compounds also supplied by plant foods, as $\beta$-carotene, vitamins $\mathrm{E}$ and $\mathrm{C}$, and certain minerals ${ }^{5}$. Lutein and zeaxanthin belong to the carotenoids group of pigments, a subgroup of the xanthophylls.

The lutein intake, from the overall diet, is higher than that of zeaxanthin in all population groups ${ }^{4,6,7}$, in a typical western diet, a ratio of $7: 1$ (lutein : zeaxanthin) has been reported in Irish subjects ${ }^{8}$ and, a ratio of 11:1 (lutein : zeaxanthin) in a group of Spanish subjects ${ }^{6}$. In the literature, the dietary intake of lutein and zeaxanthin were reported jointly until some years ago because of analytical constraints, and they are often expressed as mean values rather than the median value, which would be preferable since these dietary intakes usually do not follow a normal distribution (e.g. the lutein plus zeaxanthin dietary intake in a group of Spanish control subjects expressed as mean: $1.2 \pm$ $1.7 \mathrm{mg} /$ day and expressed as median: $0.5 \mathrm{mg}$ ) or are expressed after adjustment for energy intake. In addition, the high variability of the carotenoids intake (within and between subjects), at both the individual and group level, found in the literature is due largely to the method of dietary assessment (i.e. types of questionnaires employed) and the inconsistences in the food carotenoid composition tables and / or databases (FCT) ${ }^{9,10}$. It 
is preferable to use FCT from the country in which the assessment of carotenoid intake is being carried out; however, the main limitation of the FCT is the lack of individualized data on carotenoid content and few countries provide this type of data ${ }^{10}$. Food frequency questionnaires have been reported to overestimate carotenoid intake ${ }^{11}$ especially that of lutein and zeaxanthin when compared to 3 -day food records ${ }^{12}$.

A mean lutein and zeaxanthin of around 1-2 mg/person/day is generally reported from the dietary intake, i.e. $1.2 \mathrm{mg} / \mathrm{p} / \mathrm{d}$ in Spain and $1.4 \mathrm{mg} / \mathrm{p} / \mathrm{d}$ in the USA ${ }^{4,6,8,13,14}$.

The total dietary intake of lutein and zeaxanthin, both crude and energy- adjusted, is higher in older than in young subjects ${ }^{6,14}$, a situation that can be expected as older people consume more fruits and vegetables than young individuals ${ }^{6}$. However, this difference is not found in other studies ${ }^{15,16}$. In the literature, the differences found in the dietary lutein and zeaxanthin intake according to sex are inconsistent, as a higher intake among women has been reported ${ }^{11,17}$, but was not observed in other studies ${ }^{6,18,19}$.

\subsection{Lutein and zeaxanthin supply from fruit and vegetables}

The dietary intakes of lutein and zeaxanthin have been studied in terms of their relationship to chronic diseases, as well as to eye health / disease ${ }^{20}$, in the context of the overall diet, but to our knowledge, there is only one study in which the specific contribution of their major contributors (fruit, vegetables and eggs) to the intake of these xanthophylls or the lutein and zeaxanthin supplied by fruit and vegetables have been related to the MPOD ${ }^{21}$.

The amount of lutein and zeaxanthin supplied by vegetables is much higher than that supplied by fruits, for instance, about 10 fold in surveys carried out at national level in Spain and Brazil, according to different dietary assessments (analysis of individual consumption and household budget survey), which reported a total lutein plus zeaxanthin intake from fruit and vegetables of $0.84 \mathrm{mg} / \mathrm{p} / \mathrm{d}$ in Spain and $0.83 \mathrm{mg} / \mathrm{p} / \mathrm{d}$ in Brazil were 
reported ${ }^{21,22}$, When the lutein and zeaxanthin intake was assessed in small samples of adults, there was a higher contribution from vegetables than from fruits was described (approximately eight times), with around $85 \%$ of the lutein and zeaxanthin supplied by vegetables and $3 \%$ of lutein and $16 \%$ of zeaxanthin supplied by fruits ${ }^{6}$. This greater contribution by vegetables than by fruits is due to not only to the fact that vegetables are consumed in larger amounts ${ }^{21,22}$, but also to the fact that the amount of lutein and zeaxanthin per gram in vegetables is much higher than that in fruits ${ }^{21}$.

When the consumption of plant foods are grouped according to three groups of color (green, red/orange, white/yellow), considering that different colors could mean different phytochemicals that, in turn, would mean different health benefits; moreover, an increasing number of national and international agencies tend to emphasize the importance of eating fruit and vegetables of different colors ${ }^{23,24}$. The contribution to lutein and zeaxanthin intake in the Spanish population was higher from green fruits and vegetables $(51.1 \%)$, followed by those of red/orange color $(13.2 \%)$ and those of white/yellowish color $(21.9 \%)^{13}$.

\section{Macular pigment - a long-term marker of lutein and zeaxanthin status}

The yellow color of the macula is a consequence of the selective accumulation of lutein and zeaxanthin, dietary xanthophylls mainly supplied by vegetables, fruit and eggs and egg products, that along with meso-zeaxanthin (rarely found in diet and believed to be formed at the retina from the dietary lutein) ${ }^{25}$ constitute what is known as macular pigment.

The MP exerts a protective role in the photoreceptor cell layer from light damage by filtering blue light ${ }^{26,27}$ and acting as a scavenger of radical oxygen species; in addition, there are data showing that lutein also acts as anti-inflammation ${ }^{28}$. Higher MPOD values 
are related to an improvement in the visual function (glare disability and visual performance) ${ }^{29-31}$ and lower risk of the progression of age-related macular degeneration

(ARMD) ${ }^{32,33}$. More recently, there is increasing evidence of the role of lutein in the cognitive process and in lowering the risk of age related brain diseases ${ }^{34,35}$.

Since the identification of the composition of the MP, little more than three decades ago, as consisting lutein and zeaxanthin ${ }^{36,37}$, a number of epidemiological and clinical studies have been conducted to evaluate the role of diets ${ }^{38}$ and several food components (e.g. lutein, zeaxanthin, vitamins A, C and E, eicosapentaenoic acid [EPA], docosahexaenoic acid [DHA], zinc) in relation to ocular health, with the aims of an optimal visual function and/or a lower risk of chronic diseases (mainly the age-related macular disease) ${ }^{25,28}$. The results of these studies are, often, difficult to compare due to the imprecision or the lack of a number of aspects related to the design of the study (e.g. outcome identification, main variable used in sample size calculation, inclusion /exclusion criteria), the characteristics of the subjects (e.g. age, sex, nutritional status), methodology used in the assessment of the dietary intake (e.g. method of recording the diet and the food composition tables /databases) and of the macular pigment (i.e. no standardized equipment), the utilization of different reference values for the exposure biomarkers and for nutritional status associated with a lower risk of diseases (i.e. lutein and zeaxanthin concentrations in blood and in the diet, MP), as well as the manner used to express the results (i.e. mean, median, dietary intake per $1000 \mathrm{kcal}$, serum lutein expressed in relation to serum lipid concentration).

\subsection{Assessment of macular pigment and dietary and host-related factors}

\section{affecting its density}

The MP can be assessed by means of noninvasive methods based on the absorption spectra of the carotenoids present in the macula and is expressed as MP optical 
density (MPOD). The most widely used approach is heterochromatic flicker photometry (based on psychophysical methodology) ${ }^{39}$. The assessment of the MPOD is becoming more common due to commercially available devices that make its evaluation easy to do in clinical practice, even for untrained staff ${ }^{40}$. In general, variations in the MPOD are correlated with immediate effects on visual function ${ }^{41}$, but there are no gold standard techniques to assess visual performance ${ }^{31}$.

The MPOD is measured in density units $(\mathrm{du})$ and ranges from 0 to 1 . According to the literature, the MPOD can be classified as follows: $0.3 \mathrm{du}$ an intermediate value, $<0.2 \mathrm{du}$, a low value and $>0.5 \mathrm{du}$, a high value MPOD ${ }^{26}$. A value of MPOD of around 0.35 du was found in healthy adults of western countries $6,16,18,19$.

MP is considered a marker of long-term exposure to the dietary intake of lutein and zeaxanthin ${ }^{8,15}$ and lutein and zeaxanthin concentration in serum is considered a shortterm marker of lutein and zeaxanthin intake; those serum concentrations are widely accepted as biomarkers of fruit and vegetable intake ${ }^{42}$. MP is often positively associated with dietary and serum lutein and zeaxanthin concentrations $6,19,43$.

The assessment of the nutritional status of lutein and zeaxanthin can be carried out using biochemical and dietary methods, both of which have advantages and limitations. The best available method for the assessment of their nutritional status in human is the measurement of the serum lutein and zeaxanthin concentrations ${ }^{5,44}$. Lutein and zeaxanthin and are transported in blood to the different tissues by lipoproteins and their specific capture and deposition in the retina suggests the existence of regulated biological processes, possibly by binding proteins ${ }^{45}$ and dietary and host-related factors can influence their absorption an utilization and thus, affect their serum concentrations ${ }^{46}$.

Dietary and serum concentrations of lutein and zeaxanthin have been associated with MPOD and, a variety of fruits and vegetables as well as food supplements has been 
shown to increase the serum lutein and zeaxanthin concentrations and the MPOD, with no adverse effects reported to date at the concentrations supplied ${ }^{20,47,48}$. However, there are a number of factors affecting these relationships, including host-related factors such as age, sex, eye color, body mass index and lipid profile (and lutein plus zeaxanthin in relation to circulating lipids) and, life-style factors such as tobacco use and dietary patterns ${ }^{6,8,15,17,44,49,50}$. The MPOD has been generally reported to be lower in older vs younger subjects, as it declines with age ${ }^{6,51,52}$ despite the fact that older individuals are reported to have a higher lutein and zeaxanthin intake that younger subjects as well as higher serum concentrations of these xanthophylls ${ }^{6,43}$ this may be due to a lower capacity to respond to carotenoid consumption and thus, to inadequate uptake of circulating xanthophylls by the central retina. In an observational study of the $\mathrm{L}$ and $\mathrm{Z}$ status markers (dietary intake, serum concentrations and MPOD) in two age groups of men and women, the MPOD showed age-specific correlations with L plus $\mathrm{Z}$ expressed in relation to serum lipid concentrations (in subjects 45-65 years old), with serum lutein (in subjects aged 20$35 \mathrm{y}$.$) and with the fruit and vegetable intake (subjects 45-65$ y) ${ }^{6}$.

\section{Associations between fruit and vegetable intake and the MPOD}

The consumption of fruit and vegetables has been scarcely assessed in relationship with the MPOD, either in epidemiological or in analytical studies, with the exception of an interesting epidemiological study assessing MPOD and in which a lower risk of ARMD was associated with a higher intake of fruit but not of vegetables ${ }^{53}$ in spite of the fact that a higher intake of foods rich in those xanthophylls has been associated with a lower risk and progression of ARMD $38,53,54$

Although vegetables are greater contributors than fruits to the intake of lutein and zeaxanthin, a stronger association between fruit intake (grams) and MPOD was reported 
in a recent study. Also, fruit intake showed higher correlation than vegetable intake with lutein and zeaxanthin serum concentrations. However, no correlations were found for the relationship between MPOD and the total dietary intake of lutein and zeaxanthin. In that study, the intakes of fruit, vegetables and eggs in relationship to the lutein and zeaxanthin status markers (MPOD and their serum concentrations) were assessed in two age groups of subjects (20-35 y and 45-65y). The dietary intake was evaluated using three 24-hour diet recalls and a specific software application for the calculation of dietary intake of individual carotenoids ${ }^{55}$. Table 1 shows the intakes of lutein and zeaxanthin from fruits and vegetables and from the overall diet and the MPOD, by the group as a whole and according to age (no differences were found between sexes). These subjects $(n=108)$ consumed more vegetables than fruits, although the consumption of fruit and vegetables similar in men and women and, again, it was higher in the older age group. Correlations between the MPOD and the consumption of fruit and vegetables (grams) were reported for subjects aged 45-65 y $(\rho=0.350)$, but not for younger individuals (20 -35 y) (figure 1) ${ }^{6}$. INSERT TABLE 1 AND FIGURE 1 HERE

In a subsequent statistical analysis, the intake of lutein and zeaxanthin supplied by each of the three major food contributors to their dietary intake (fruit, vegetables and eggs) was evaluated to determine their association with the MPOD. The lutein and zeaxanthin intake derived from fruits showed a significant association with the MPOD but no significant association was observed with the intake of these xanthophylls from eggs and vegetables, although vegetables provided approximately eight times more lutein and zeaxanthin than fruits ${ }^{21}$.

When the food source was grouped according the color of the edible portion (green, red/orange, white/yellow), the intake from fruit and vegetables was similar between sexes but there were differences between the age groups, being higher in the 
older group. The foods of plant origin (considering not only fruit and vegetables, but also sauces, as ketchup, and orange and tomato juices) that supplied the highest amount of lutein and zeaxanthin were those of green color (78\% and 52\%, respectively), followed by red/orange color ( $9 \%$ of lutein and $38 \%$ of zeaxanthin intake) and white/yellow color $(14 \% \text { and } 9 \%)^{21}$. However, the lutein and zeaxanthin intake from red/orange foods (but not from green or white/yellow foods) was related to the MPOD (rho=0.320) and that from green foods with the serum concentrations (rho=0.222) but not with the MPOD, in spite of the fact that green foods of plant origin are the major contributors to lutein and zeaxanthin intake ${ }^{21}$. Because of this and because most of the foods included in the carotenoid composition database were of green color, we used factorial analysis of the variables MPOD, lutein and zeaxanthin intake supplied by fruits, vegetables and eggs, Lutein and zeaxanthin intake supplied by plant foods grouped according to their color and the lutein+zeaxanthin serum concentration and found independence in the younger subjects (20-35 y), but a significant association between the lutein plus zeaxanthin intake and their status markers in the older subjects (45-65 y). Figure 2 shows the correlation matrix for MPOD, lutein plus zeaxanthin serum concentration and luein pluz zeaxanthin intake from the three major contributors to their dietary intake in the older group of subjects ${ }^{21}$. MPOD is related to the lutein plus zeaxanthin intake from fruits (rho=0.264), but independent of that from vegetables and eggs. Figure 3 shows the associations among those variables but considering the lutein plus zeaxanthin intakes from plant foods grouped according to their color, in the older group, as well ${ }^{21}$. This unexpected result could be due to the different bioavailabilities of these carotenoids from the food matrices. In fruits, xanthophylls are found in the ester forms, which could have higher bioavailability than free forms ${ }^{56,57}$, or not ${ }^{56}$. On the other hand, the bioaccessibility could be different depending on the localization of the xanthophylls in the plant, thus; in fact, 
the carotenoids in fruits are found mainly in chromoplasts and are more easily released by digestion than when present in green vegetables, which are mainly located in chloroplasts ${ }^{9,58,59}$. INSERT FIGURES 2 AND 3 HERE

A summary of studies investigating the relationship between MPOD and the intake of lutein and zeaxanthin $(\mu \mathrm{g} / \mathrm{p} / \mathrm{d})$, mainly from the overall diet and a few of them providing the intake from fruit and vegetables, is shown in table 2. Initially, as can be seen in the table, the objective of studies on the intake of lutein and zeaxanthin and the MPOD is to quantify this association, as well as the influence of certain variables that could be potential modifiers of that relationship, such as sex, age, body mass index, the presence or absence of ocular disease (i.e. ARMD). Subsequently, other variables are the object of studies, as are genotypic differences, family history of ARMD, the influence of certain foods or specific food groups, as well as the assessment of the effect of lutein and zeaxanthin supplementation. The association between intake and MPOD can present biases derived from the utilization of different measuring procedures, an aspect that should be homogenized, although standardized procedures are still not employed. In the studies compiled in table 2 , it is observed that, in most cases, dietary assessment was performed utilizing food frequency questionnaires, which can differ in design and content, and with respect to the food composition tables /databases used, there is a wide variability. In most of the studies included, the evaluation of the dietary intake of lutein and zeaxanthin measures them jointly and this intake has a mean value of between 1 and $2 \mathrm{mg} /$ day. In some studies, it is the intake of foods that are good sources of lutein and zeaxanthin in the diet, either food groups such as fruit and vegetables ${ }^{60-62}$ or specific foods such as Chinese wolfberry ${ }^{63,64}$ or corn oil ${ }^{63}$, that is assessed in relation to the MPOD. With respect to the methodology utilized to evaluate the MPOD, the approach most widely used is heterochromatic flicker photometry, which has the limitations 
derived from being a psychophysical methodology, but its reliability has been the subject of a number of studies ${ }^{49}$. The values of MPOD are generally in the range of $0.30-0.40$ d.u ${ }^{6,16,17,19,61}$, with certain exceptions found in studies with mean values lower than 0.20 du. ${ }^{60}$ or higher ${ }^{62,63,65,66}$. There are also differences observed in the form of expressing the results and, thus, in some cases the MPOD is expressed as a single value and other authors provide data on several loci, which, moreover, differ from one study to another. Given the comments on the table 2, it can be said that is difficult to establish comparisons across studies that assess the dietary intake of lutein and zeaxanthin or that of their major dietary contributors and the MPOD. In general, there are correlations between a higher fruit and vegetable intake or of a higher lutein and zeaxanthin intake and a higher MPOD, with some exceptions ${ }^{67}$.

INSERT TABLE 2 HERE

\section{Dietary intake recommendations on visual health}

Ocular health can become deteriorated when there is an insufficient dietary contribution of the nutrients implicated in vision, such as retinol, the deficiency of which leads to clinical eye symptoms ${ }^{3}$ but there are also other bioactive compounds, like lutein and zeaxanthin, associated with a lower risk of ARMD ${ }^{32,33}$. However, the majority of the population is unaware of the importance of nutrients in terms of ocular health, although vision is generally considered to be the most important of the five senses ${ }^{68}$.

In general, there is no public health recommendations on the intake of specific foods or of their components for the purpose of maintaining ocular health or of reducing the risk of ocular diseases associated with aging. However, although there are no reference intakes for carotenoids, including lutein and zeaxanthin, there are sufficient data supporting recommendations that we increase the consumption of of fruit and vegetables 
(with a variety of colors), the food groups that contribute nearly all of these components in the diet, as a dietary factor associated with a lower risk a number of chronic diseases ${ }^{23,24,69}$. On the other hand, although, currently, there is no consensus on the part of scientific organizations or in the public health setting concerning recommendations on lutein and zeaxanthin intake, the need to establish reference dietary recommendations has been proposed for lutein, as this compound meets a series of overall criteria established for nonessential bioactive components in the diet/health relationship ${ }^{70}$. Specifically, regarding eye health, a higher intake of a variety of fruit and vegetables, and food supplements, has been shown to increase in the MPOD and this, along with serum lutein have been described as predictors of visual function (assessing the contrast sensitivity) in a group of subjects aged $45-65$ years ${ }^{71}$.

There is numerous data on the content of lutein and zeaxanthin in foods and human serum, provided by epidemiological and in vitro and in vivo studies, and using them as a basis, some authors suggest that a recommendable intake be that which achieves a concentration of serum lutein in a range between 0.6 y $1.05 \mu \mathrm{mol} / \mathrm{l}(34-60 \mu \mathrm{g}$ lutein/dL), since those levels have been associated with beneficial effects, with no risk of secondary effects ${ }^{20}$. This lutein concentration can be reached with a mean intake of $6 \mathrm{mg}$ lutein/day from foods with a high content in lutein, but also by means of food supplements and functional foods. However, in general, it is simpler to achieve the concentration desired in blood by means of food supplements, since bioavailability of extracts is greater than that provided by foods, whose bioavailability is highly variable due to the influence of food related factors (i.e. chemical form of xanthophylls, content of fiber, location in chloro- or chromoplastos) ${ }^{72}$.

Finally, aside from the dietary recommendation that the general population increase the consumption of fruits and vegetables, certain scientific organisms specify the 
consumption of green-colored foods to achieve and increase in the intake of lutein and zeaxanthin (i.e. USDA 2011) ${ }^{23}$ and, thus, a better nutritional status of these compounds associated with a lower risk of certain chronic ocular diseases and improvement of visual function. However, we must remember that the dietary contribution of lutein and zeaxanthin is not the only determinant of an increase in MPOD, since this is, for example, facilitated with the simultaneous intake of omega-3 fatty acids. On the other hand, a high content of these compounds in foods (in green vegetables) is not the only requirement to facilitate and increase in the macular pigment. It is essential to know their bioavailability supplied by each food matrix, and, it seems, that this is higher in plant foods of red/orange color (mainly fruits) than those of green color. This is an aspect that should be extensively studied.

\section{References}

1. WHO technical staff. Increasing fruit and vegetable consumption to reduce the risk of noncommunicable diseases. September, 2014. http://www.who.int/elena/titles/fruit_vegetables_ncds/en/ Accessed 1 June 2018.

2. Slavin JL, Lloyd B. Health benefits of fruits and vegetables. Adv Nutr. 2012;3(4):506-516.

3. WHO. Action plan for the prevention of avoidable blindness and visual impairment 2009-2013. 2010.

4. Shardell M, Alley D, Hick G, El-Kamary S. Low-serum carotenoid concentrations and carotenoid interactions predict mortality in US adults: the Third National Health and Nutrition Examination Survey. Nutr Res. 2011;31:178-189.

5. Lien EL, Hammond BR. Nutritional influences on visual development and function. Prog Retinal Eye Res. 2011;30(3):188-203.

6. Olmedilla-Alonso B, Beltran-de-Miguel B, Estevez-Santiago R, Cuadrado-Vives C. Markers of lutein and zeaxanthin status in two age groups of men and women: dietary intake, serum concentrations, lipid profile and macular pigment optical density. Nutr J. $2014 ; 13$.

7. Olmedilla B, Granado F, Southon S, et al. Serum concentrations of carotenoids and vitamins $\mathrm{A}, \mathrm{E}$, and $\mathrm{C}$ in control subjects from five European countries. Brit $\mathrm{J}$ Nutr. 2001;85(2):227-238. 
8. Beatty S, Nolan J. Macular pigment optical density and its relationship with serum and dietary levels of lutein and zeaxanthin. Arch biochem biophys. 2004;430:70-76.

9. Maiani G, Periago Caston MJ, Catasta G, et al. Carotenoids: Actual knowledge on food sources, intakes, stability and bioavailability and their protective role in humans. Mol Nutr Food Res. 2009;53:S194-S218.

10. Dias MG, Olmedilla-Alonso B, Hornero-Mendez D, et al. Comprehensive Database of Carotenoid Contents in Ibero-American Foods. A Valuable Tool in the Context of Functional Foods and the Establishment of Recommended Intakes of Bioactives. J Agric Food Chem. 2018;66(20):5055-5107.

11. George SM, Thompson FE, Midthune D, et al. Strength of the relationships between three self-reported dietary intake instruments and serum carotenoids: the Observing energy and protein Nutrition (OPEN) Study. Publ Health Nutr. 2012;15(6):1000-1007.

12. Granado-Lorencio F, Olmedilla-Alonso B, Blanco-Navarro I, Botella-Romero F, Simal-Anton A. Assessment of carotenoid status and the relation to glycaemic control in type I diabetics: a follow-up study. Eur J Clin Nutr. 2006;60(8):1000-1008.

13. Estévez-Santiago R, Beltrán de Miguel B, Olmedilla Alonso B. Assessment of dietary lutein, zeaxanthin and lycopene intake and their sources in the National Survey of Dietary Intake in Spain (2009-2010). . Int J Food Sci Nutr 2016;67(3):305-313.

14. Johnson EJ, Maras JE, Rasmussen HM, Tucker KL. Intake of Lutein and Zeaxanthin Differ with Age, Sex, and Ethnicity. J Am Diet Assoc. 2010;110(9):13571362.

15. Cardinault N, Gorrand J-M, Tyssandier V, Grolier P, Rock E, Borel P. Short-term supplementation with lutein affects biomarkers of lutein status similarly in young and elderly subjects. Exp Gerontol. 2003;38:573-582.

16. Berrow EJ, Bartlett HE, Eperjesi F. Do lutein, zeaxanthin and macular pigment optical density differ with age or age-related maculopathy? e-SPEN, the European eJournal of Clinical Nutrition and Metabolism. 2011;6(4):e197-e201.

17. Wenzel AJ, Sheehan JP, Burke JD, Lefsrud MG, Curran-Celentano J. Dietary intake and serum concentrations of lutein and zeaxanthin, but not macular pigment optical density, are related in spouses. Nutr Res. 2007;27(8):462-469.

18. Hammond BR, CurranCelentano J, Judd S, et al. Sex differences in macular pigment optical density: Relation to plasma carotenoid concentrations and dietary patterns. Vision Res. 1996;36(13):2001-2012.

19. Burke JD, Curran-Celentano J, Wenzel AJ. Diet and serum carotenoid concentrations affect macular pigment optical density in adults 45 years and older. J Nutr. 2005;135(5):1208-1214.

20. Granado F, Olmedilla B, Blanco I. Nutritional and clinical relevance of lutein in human health. Brit J Nutr. 2003;90(3):487-502. 
21. Estevez-Santiago R, Olmedilla-Alonso B, Beltran-de-Miguel B, Cuadrado-Vives C. Lutein and zeaxanthin supplied by red/orange foods and fruits are more closely associated with macular pigment optical density than those from green vegetables in Spanish subjects. Nutr Res. 2016;36(11):1210-1221.

22. Vargas-Murga L, de Rosso VV, Mercadante AZ, Olmedilla-Alonso B. Fruits and vegetables in the Brazilian Household Budget Survey (2008-2009): carotenoid content and assessment of individual carotenoid intake. J Food Compos Anal. 2016;50:88-96.

23. USDA. Center for Nutrition Policy and Promotion. Dietary guidelines for $\begin{array}{lllll}\text { americans. } & \text { Accessed } & 7 & \text { June } & 2018\end{array}$ https://www.cnpp.usda.gov/sites/default/files/dietary_guidelines_for_americans/2000D GBrochureFabulousFruits.pdf.

24. WCRF. Food, Nutrition, Physical Activity, and the Prevention of Cancer: A Global Perspective. Washington DC2007.

25. Bernstein PS, Li B, Vachali PP, et al. Lutein, zeaxanthin, and meso-zeaxanthin: The basic and clinical science underlying carotenoid-based nutritional interventions against ocular disease. Prog Retinal Eye Res. 2016;50:34-66.

26. Bernstein PS, Delori FC, Richer S, van Kuijk FJM, Wenzel AJ. The value of measurement of macular carotenoid pigment optical densities and distributions in agerelated macular degeneration and other retinal disorders. Vision Res. 2010;50(7):716728.

27. Snodderly DM. Evidence for protection against age-related macular degeneration by carotenoids and antioxidant vitamins. Am J Clin Nutr. 1995;62(6 Suppl):1448S$1461 S$.

28. Mares J. Lutein and Zeaxanthin Isomers in Eye Health and Disease. Annu Rev Nutr. 2016;36:771-602.

29. Stringham JM, Hammond BR, Jr. The glare hypothesis of macular pigment function. Optometry and Vision Science. 2007;84(9):859-864.

30. Hammond BR, Fletcher LM, Roos F, Wittwer J, Schalch W. y A Double-Blind, Placebo-Controlled Study on the Effects of Lutein and Zeaxanthin on Photostress Recovery, Glare Disability, and Chromatic Contrast. Invest Ophthalmol Visual Sci. 2014;55(12):8583-8589.

31. Loughman J, Akkali MC, Beatty S, et al. The relationship between macular pigment and visual performance. Vision Res. 2010;50(13):1249-1256.

32. Age-Related Eye Disease Study 2 Research G. Lutein + zeaxanthin and omega-3 fatty acids for age-related macular degeneration: the Age-Related Eye Disease Study 2 (AREDS2) randomized clinical trial. Jama. 2013;309(19):2005-2015.

33. Kassoff A, Kassoff J, Buehler J, et al. A randomized, placebo-controlled, clinical trial of high-dose supplementation with vitamins $\mathrm{C}$ and $\mathrm{E}$, beta carotene, and zinc for agerelated macular degeneration and vision loss - AREDS Report No. 8. Arch Ophthalmol. 2001;119(10):1417-1436. 
34. Lindbergh CA, Renzi-Hammond LM, Hammond BR, et al. Lutein and Zeaxanthin Influence Brain Function in Older Adults: A Randomized Controlled Trial. J Int Neuropsychol Soc. 2018;24(1):77-90.

35. Lindbergh CA, Mewborn CM, Hammond BR, Renzi-Hammond LM, CurranCelentano JM, Miller LS. Relationship of Lutein and Zeaxanthin Levels to Neurocognitive Functioning: An fMRI Study of Older Adults. J Int Neuropsychol Soc. 2017;23(1):11-22.

36. Bone RA, Landrum JT, Tarsis SL. Preliminary identification of the human macular pigment. Vision Res. 1985;25(11):1531-1535.

37. Handelman GJ, Dratz EA, Reay CC, Vankuijk F. Carotenoids in the human macula and whole retina. Invest Ophthalmol Visual Sci. 1988;29(6):850-855.

38. Seddon JM, Ajani UA, Sperduto RD, et al. Dietary carotenoides, vitamin-A, vitamin-C and vitamin-E, and advanced age-related macular degeneration. JAMA, J Am Med Assoc. 1994;272(18):1413-1420.

39. van der Veen RLP, Berendschot TTJM, Hendrikse F, Carden D, Makridaki M, Murray IJ. A new desktop instrument for measuring macular pigment optical density based on a novel technique for setting flicker thresholds. Ophthalmic and Physiological Optics. 2009;29(2):127-137.

40. de Kinkelder R, van der Veen RLP, Verbaak FD, Faber DJ, van Leeuwen TG, Berendschot TTJM. Macular pigment optical density measurements: evaluation of a device using heterochromatic flicker photometry. Eye. 2011;25(1):105-112.

41. Hammond BR, Jr., Fletcher LM, Elliott JG. Glare Disability, Photostress Recovery, and Chromatic Contrast: Relation to Macular Pigment and Serum Lutein and Zeaxanthin. Invest Ophthalmol Visual Sci. 2013;54(1):476-481.

42. Souverein OW, de Vries JHM, Freese R, et al. Prediction of fruit and vegetable intake from biomarkers using individual participant data of diet-controlled intervention studies. Brit J Nutr. 2015;113(9):1396-1409.

43. AREDS2 (Age-Related Eye Disease Study 2)

44. Carpentier S. Associations between Lutein, Zeaxanthin, and Age-Related Macular Degeneration: An Overview. Crit Rev Food Sci Nutr. 2009;49:313-326.

45. Rodriguez-Concepcion M, Avalos J, Bonet ML, et al. A global perspective on carotenoids: Metabolism, biotechnology, and benefits for nutrition and health. Progress in lipid research. 2018;70:62-93.

46. Thurnham DI. Macular zeaxanthins and lutein - a review of dietary sources and bioavailability and some relationships with macular pigment optical density and agerelated macular disease. Nutr Res Rev. 2007;20(2):163-179.

47. EFSA Panel on Food Additives and Nutrient Sources added to Food. Scientific Opinion on the re-evaluation of lutein (E 161b) as a food additive on request of the 
European Commission. EFSA Journal 2010; 8(7):1678 [57 $\quad$ pp.]. Doi:10.2903/j.efsa.2010.1678. Available online: www.efsa.europa.eu

48. EFSA Panel on Dietetic Products and Allergies. Opinion on the substantiation of health claims related to lutein and maintenance of normal vision (ID 1603, 1604, further assessment) pursuant to Article 13(1) of Regulation (EC) No 1924/2006. EFSA Journal 2012; 10(6):2716. Available online: www.efsa.europa.eu/efsajourna

49. Murray IJ. Macular Pigment: Characteristics and Role in the Older Eye. In: Werner J, Chalupa L. Eds. The new visual neurosciences. London: MIT Press Cambridge; 2014.

50. Makridaki M, Carden D, Murray IJ. Macular pigment measurement in clinics: controlling the effect of the ageing media. Ophthalmic and Physiological Optics. 2009;29(3):338-344.

51. Hammond BR, Wooten BR, Snodderly DM. Preservation of visual sensitivity of older subjects: Association with macular pigment density. Invest Ophthalmol Visual Sci. 1998;39(2):397-406.

52. Berendschot TT, van Norren D. On the age dependency of the macular pigment optical density. Exp Eye Res. 2005;81(5):602-609.

53. Cho EY, Seddon JM, Rosner B, Willett WC, Hankinson SE. Prospective study of intake of fruits, vegetables, vitamins, and carotenoids and risk of age-related maculopathy. Arch Ophthalmol 2004;122(6):883-892.

54. Mares-Perlman JA, Fisher AI, Klein R, Block G, Millen AE, Wright JD. Lutein and zeaxanthin in the diet and serum and their relation to age-related maculopathy in the Third National Health and Nutrition Examination Survey. Am J Epidemiol. 2001;153(5):424-432.

55. Estévez-Santiago R, Beltrán-de-Miguel B, Cuadrado-Vives C, Olmedilla-Alonso B. Software application for the calculation of dietary intake of individual carotenoids and of its contribution to vitamin A intake. Nutr Hosp. 2013;28((3)):823-829.

56. Bunea A, Socaciu C, Pintea A. Xanthophyll Esters in Fruits and Vegetables. Not Bot Horti Agrobot Cluj-Napoca. 2014;42(2):310-324.

57. Olmedilla-Alonso B, Granado-Lorencio F, Castro-Feito J, Herrero-Barbudo C, Blanco-Navarro I, Pérez-Sacristán B. Bioavailability of lutein (free and ester forms) in humans: assessment using exposition and functional biomarkers. Acta Biochim Pol. 2008;55:4-5.

58. Schweiggert RM, Mezger D, Schimpf F, Steingass CB, Carle R. Influence of chromoplast morphology on carotenoid bioaccessibility of carrot, mango, papaya, and tomato. Food Chem. 2012;135(4):2736-2742.

59. Pee Sd, West CE, Permaesih D, Martuti, Muhilal, Hautvast JGAJ. Orange fruit is more effective than are dark-green, leafy vegetables in increasing serum concentrations of retinol and beta-carotene in schoolchildren in Indonesia. Am $\mathbf{J}$ Clin Nutr. 1998;68(5):1058-1067. 
60. Curran-Celentano J, Hammond BR, Ciulla TA, Cooper DA, Pratt LM, Danis RB. Relation between dietary intake, serum concentrations, and retinal concentrations of lutein and zeaxanthin in adults in a Midwest population. Am J Clin Nutr. 2001;74(6):796802.

61. Mares J, LaRowe TL, Snodderly DM, et al. Predictors of optical density of lutein and zeaxanthin in retinas of older women in the Carotenoids in Age-related Eye Disease Study, an ancillary study of the Women's Health Initiative. Am J Clin Nutr. 2006;84:1107-1122.

62. Kyle-Little Z, Zele AJ, Morris CP, Feigl B. The Effect of BCMO1 Gene Variants on Macular Pigment Optical Density in Young Healthy Caucasians. Front Nutr. 2014;1:22-22.

63. Ren X-T, Gu H, Han X, et al. Measurement of macular pigment optical density among healthy Chinese people and patients with early-stage age-related macular degeneration. Int J Ophthalmol (Engl Ed). 2015;8(6):1190-1195.

64. She C-Y, Gu H, Xu J, Yang X-F, Ran X-T, Liu N-P. Association of macular pigment optical density with early stage of non-proliferative diabetic retinopathy in Chinese patients with type 2 diabetes mellitus. Int J Ophthalmol (Engl Ed). 2016;9(10):1433-1438.

65. Nagai N, Izumi-Nagai K, Suzuki M, et al. Association of macular pigment optical density with serum concentration of oxidized low-density lipoprotein in healthy adults. Retina-the Journal of Retinal and Vitreous Diseases. 2015;35(4):820-826.

66. Khan NA, Walk AM, Edwards CG, et al. Macular Xanthophylls Are Related to Intellectual Ability among Adults with Overweight and Obesity. Nutrients. 2018;10(4).

67. Alassane S, Binquet C, Cottet V, et al. Relationships of Macular Pigment Optical Density With Plasma Lutein, Zeaxanthin, and Diet in an Elderly Population: The Montrachet Study. Invest Ophthalmol Visual Sci. 2016;57(3):1160-1167.

68. Rasmussen HM, Johnson EJ. Nutrients for the aging eye. Clin Interventions Aging. 2013;8:741-748.

69. WHO/FAO. Global Strategy on Diet, Physical Activity and Health: Promoting fruit and vegetable consumption around the world. 2003; http://www.who.int/dietphysicalactivity/fruit/en/. Accessed 08/07/2015, 2015.

70. Ranard KM, Jeon S, Mohn ES, Griffiths JC, Johnson EJ, Erdman JW. Dietary guidance for lutein: consideration for intake recommendations is scientifically supported. Eur J Nutr. 2017;56:537-542.

71. Estevez-Santiago R, Olmedilla-Alonso B, Beltran-de-Miguel B. Assessment of lutein and zeaxanthin status and dietary markers as predictors of the contrast threshold in 2 age groups of men and women. Nutr Res. 2016;36(7):719-730.

72. Schweiggert RM, Steingass CB, Heller A, Esquivel P, Carle R. Characterization of chromoplasts and carotenoids of red- and yellow-fleshed papaya ( Carica papaya L.). Planta. 2011;234(5):1031-1044. 
73. Bone RA, Landrum JT, Dixon Z, Chen Y, Llerena CM. Lutein and zeaxanthin in the eyes, serum and diet of human subjects. Exp Eye Res. 2000;71(3):239-245.

74. Ciulla TA, Curran-Celantano J, Cooper DA, et al. Macular pigment optical density in a midwestern sample. Ophthalmology. 2001;108(4):730-737.

75. Nolan JM, Stack J, O'Connell E, Beatty S. The relationships between macular pigment optical density and its constituent carotenoids in diet and serum. Invest Ophthalmol Visual Sci. 2007;48(2):571-582.

76. O'Neill ME, Carroll Y, Corridan B, et al. A European carotenoid database to assess carotenoid intakes and its use in a five-country comparative study. Brit $\mathbf{J}$ Nutr. 2001;85(4):499-507.

77. Holden J, Bhagwat S, Beecher G, et al. USDA/NCC database for carotenoids in US foods. FASEB J. 1998;12(4):A543-A543.

78. Beltran B, Estevez R, Cuadrado C, Jimenez S, Olmedilla Alonso B. Carotenoid data base to assess dietary intake of carotenes, xantophyls and vitamina-A; its use in a comparaative study of vitamin-A status in young adults. Nutr Hosp. 2012;27(4):13341343.

79. Sommerburg O, Keunen JEE, Bird AC, van Kuijk F. Fruits and vegetables that are sources for lutein and zeaxanthin: the macular pigment in human eyes. $\mathrm{Br} \mathbf{J}$ Ophthalmol. 1998;82(8):907-910. 


\begin{tabular}{|c|c|c|c|c|}
\hline & & $\begin{array}{l}\text { Subjects 20-35 y } \\
(n=54)\end{array}$ & $\begin{array}{l}\text { Subjects 45-65 y } \\
(n=54)\end{array}$ & $\begin{array}{l}\text { Total sample } \\
(n=108)\end{array}$ \\
\hline \multirow{3}{*}{$\begin{array}{c}\text { Lutein + } \\
\text { zeaxanthin } \\
(\mu \mathrm{g} / \text { day })\end{array}$} & From fruits & $\begin{array}{l}32.6 \pm 36.7 \\
(19.5)\end{array}$ & $\begin{array}{l}74.3 \pm 70.3 \\
(68.2)\end{array}$ & $\begin{array}{l}53.4 \pm 59.7 \\
(34.1)\end{array}$ \\
\hline & From vegetables & $\begin{array}{l}902.5 \pm 1714.1 \\
(264.3)\end{array}$ & $\begin{array}{l}1258.4 \pm 1731.2 \\
(399.9)\end{array}$ & $\begin{array}{l}1080.4 \pm 1727.9 \\
(317.9)\end{array}$ \\
\hline & From overall diet & $\begin{array}{l}995.4 \pm 1705 \\
(369)\end{array}$ & $\begin{array}{l}1341.1 \pm 1693.1 \\
(678.6)\end{array}$ & $\begin{array}{l}1168.3 \pm 1700 \\
(451)\end{array}$ \\
\hline \multicolumn{2}{|c|}{ Fruit intake (g/day) } & $\begin{array}{l}150.4 \pm 119 \\
(151.9)\end{array}$ & $\begin{array}{l}298.4 \pm 212.1 \\
(269.2)\end{array}$ & $\begin{array}{l}224.4 \pm 186.9 \\
(197.5)\end{array}$ \\
\hline \multicolumn{2}{|c|}{ Vegetable intake (g/day) } & $\begin{array}{l}238.9 \pm 127.8 \\
(231)\end{array}$ & $\begin{array}{l}311.9 \pm 158.7 \\
(290.7)\end{array}$ & $\begin{array}{l}274.9 \pm 148.4 \\
(266.3)\end{array}$ \\
\hline \multicolumn{2}{|l|}{ MPOD $(\mathrm{du})$} & $\begin{array}{l}0.37 \pm 0.14 \\
(0.36)\end{array}$ & $\begin{array}{l}0.33 \pm 0.16 \\
(0.32)\end{array}$ & $\begin{array}{l}0.35 \pm 0.11 \\
(0.36)\end{array}$ \\
\hline
\end{tabular}


Table 2.

\begin{tabular}{|c|c|c|c|c|c|c|c|c|}
\hline $\begin{array}{l}\text { Study } \\
\text { author(s), } \\
\text { year [ref.] }\end{array}$ & $\stackrel{\Xi}{\Xi}$ & $\begin{array}{l}\text { N sample, } \\
\text { Healthy } \\
\text { /diseased } \\
\text { Age } \\
\text { Sex }\end{array}$ & $\begin{array}{l}\text { Dietary intake } \\
\text { assessment } \\
\text { method / FCT }\end{array}$ & $\begin{array}{l}\text { Dietary intake of } \\
\text { lutein }(\mathbf{L}) \text { and } \\
\text { zeaxanthin }(\mathbf{Z}) \\
(\mu \mathrm{g} / \text { day) or fruit and } \\
\text { vegetables }(\mathbf{F}, \mathbf{V}) \\
(\mathrm{g} / \text { day) } \\
\text { Mean }(\mathrm{SD}),[\text { Median] }\end{array}$ & 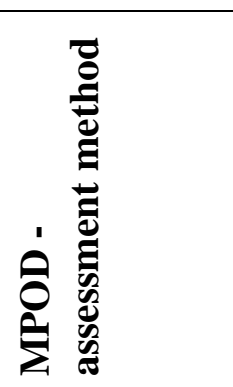 & $\begin{array}{l}\text { MPOD }(\mathrm{du}) \\
\text { Mean }(\mathrm{SD})\end{array}$ & $\begin{array}{l}\text { Statistical } \\
\text { analysis } \\
\text { (MPOD and } \\
\text { L+Z dietary } \\
\text { intake) }\end{array}$ & $\begin{array}{l}\text { Result } \\
\text { (association between } \\
\text { MPOD and dietary } \\
\text { intake) }\end{array}$ \\
\hline $\begin{array}{l}\text { Hammond } \\
\text { et al, } 1996 \\
18\end{array}$ & USA & $\begin{array}{l}88 \\
\text { Healthy } \\
19-83 y\end{array}$ & $\begin{array}{l}\text { - Health habits } \\
\text { and history } \\
\text { questionnaire. } \\
\text {-Diet system } \\
\text { analysis software }\end{array}$ & $\begin{array}{l}\mathrm{L}+\mathrm{Z} \\
\mathrm{W}: 2091(1973) \\
\mathrm{M}: 3125(2618) \\
\text { (NS differences) }\end{array}$ & $\begin{array}{l}\text { Three- } \\
\text { channel,Ma } \\
\text { xwellian } \\
\text { view optical } \\
\text { system }\end{array}$ & $\begin{array}{l}\text { W: } 0.24(0.16) \\
\text { M: } 0.38(0.22) \\
\text { Significant } \\
\text { differences }\end{array}$ & $\begin{array}{l}\text { Pearson } \\
\text { correlation }\end{array}$ & $\begin{array}{l}\mathrm{W}: \mathrm{ns} \\
\mathrm{M}: r=0.64\end{array}$ \\
\hline $\begin{array}{l}\text { Bone et al, } \\
2000^{73}\end{array}$ & USA & $\begin{array}{l}19 \\
\text { Healthy } \\
18-59 y\end{array}$ & $\begin{array}{l}\text { Health Habits and } \\
\text { History } \\
\text { questionnaire } \\
\text { Nutritionist V } \\
\text { (First Data Bank, } \\
\text { CA, USA) }\end{array}$ & Values not given & HFP & Not reported & $\begin{array}{l}\text { Lineal } \\
\text { regression }\end{array}$ & $\begin{array}{l}r=0,42(\mathrm{p}<001) \\
17 \% \text { of the variability } \\
\text { of MPOD is explained } \\
\text { by } \mathrm{L}+\mathrm{Z} \text { intake }\end{array}$ \\
\hline $\begin{array}{l}\text { Curran- } \\
\text { Celentano } \\
\text { et al, 200160 }\end{array}$ & USA & $\begin{array}{l}280 \\
\text { Healthy } \\
18-50 y\end{array}$ & $\begin{array}{l}\text { FFQ } \\
\text { University of } \\
\text { Minnesota } \\
\text { Nutrition } \\
\text { Coordinating }\end{array}$ & $\begin{array}{l}\text { Fruit (servings/day): } \\
1.2(1.1) \\
\\
\text { Vegetables } \\
\text { (servings/day): } \\
1.4(1.1)\end{array}$ & HFP & $0.21(0.13)$ & $\begin{array}{l}\text { Pearson } \\
\text { correlation }\end{array}$ & $r=0.21 \mathrm{p}<0.001$ \\
\hline
\end{tabular}




\begin{tabular}{|c|c|c|c|c|c|c|c|c|}
\hline & & & $\begin{array}{l}\text { Center nutrient } \\
\text { database }\end{array}$ & L+Z: 1101 (838) & & & & \\
\hline $\begin{array}{l}\text { Ciulla et al., } \\
2001^{74}\end{array}$ & USA & $\begin{array}{l}280 \\
\text { Healthy } \\
18-50 y\end{array}$ & $\begin{array}{l}\text { FFQ } \\
\text { University of } \\
\text { Minnesota } \\
\text { Nutrition } \\
\text { Coordinating } \\
\text { Center nutrient } \\
\text { database }\end{array}$ & L + Z: 1102 (839) & HFP & Not reported & $\begin{array}{l}\text { General } \\
\text { linear model } \\
(\text { GLM) } \\
\text { Spearman } \\
\text { correlation }\end{array}$ & $\begin{array}{l}\text { Lineal regression: } \\
\mathrm{L}+\mathrm{Z} \text { intake explains } \\
2.01 \% \text { of the } \\
\text { variability of MPOD } \\
\text { ( } \mathrm{p}=0.014) \\
\text { Fruit consumption } \\
\text { explains } 0.72 \% \text { ( } p= \\
0.141) \\
\text { Rho, with MPOD: } \\
\text { L+Z intake: } 0.17 \\
\text { Vegetable intake: NS } \\
\text { Fruit intake: } 0.15\end{array}$ \\
\hline
\end{tabular}




\begin{tabular}{|c|c|c|c|c|c|c|c|c|}
\hline $\begin{array}{l}\text { Burke et al, } \\
2005^{19}\end{array}$ & USA & $\begin{array}{l}108 \\
\text { Healthy } \\
45-75 y\end{array}$ & $\begin{array}{l}\text { FFQ } \\
\text { University of } \\
\text { Minnesota } \\
\text { Nutrition } \\
\text { Coordinating } \\
\text { Center nutrient } \\
\text { database }\end{array}$ & $\begin{array}{l}\mathrm{L}+\mathrm{Z}: \\
\mathrm{W}: 1832 \quad(166) \\
\mathrm{M}: 1474 \text { (109) } \\
\text { (NS differences) }\end{array}$ & $\begin{array}{l}\text { HFP } \\
\left(10^{\prime}, 30^{\prime},\right. \\
\left.60^{\prime}, 120^{\prime}\right)\end{array}$ & $\begin{array}{l}\text { 10' } \\
\text { W: } 0.42(0.02) \\
\text { M: } 0.45(0.02) \\
30^{\prime} \\
\text { W: } 0.36(0.02) \\
\text { M: } 0.35(0.02) \\
60^{\prime} \\
\text { W: } 0.27(0.02) \\
\text { M: } 0.27(0.01) \\
\text { 120' } \\
\text { W: } 0.13(0.01) \\
\text { M: } 0.11(0.01) \\
\text { NS differences }\end{array}$ & $\begin{array}{l}\text { Pearson } \\
\text { Product } \\
\text { Moment } \\
\text { Correlation }\end{array}$ & $\begin{array}{l}\text { The lowest fruit and } \\
\text { vegetable intake } \\
\text { category had the } \\
\text { lowest MPOD, and } \\
\text { those with the highest } \\
\text { intake had the highest } \\
\text { MPOD at all sites }\end{array}$ \\
\hline
\end{tabular}




\begin{tabular}{|c|c|c|c|c|c|c|c|c|}
\hline $\begin{array}{l}\text { Mares et al, } \\
2006^{61}\end{array}$ & USA & $\begin{array}{l}1698 \\
\text { Healthy } \\
\text { 53-86y } \\
\text { Women }\end{array}$ & $\begin{array}{l}\text { SFFQ } \\
(\text { Servings of } \mathrm{F}+\mathrm{V}) \\
\text { CAREDS }\end{array}$ & $\begin{array}{l}\text { Quintiles } \\
\mathrm{L}+\mathrm{Z}: \\
1^{\text {st. }}:[0.8] \\
2^{\text {nd. }}:[1.4] \\
3^{\text {rd }}:[2.1] \\
4^{\text {th: }}:[3.1] \\
5^{\text {th }}:[5.3] \\
\\
\text { Servings of F+V } \\
1^{\text {st. }:[1.6]} \\
2^{\text {nd. }}:[2.7] \\
3^{\text {rd }}:[4.1] \\
4^{\text {th. }}:[5.6] \\
5^{\text {th }}:[7.6]\end{array}$ & HFP & $\begin{array}{l}\text { Quintile L+Z: } \\
1^{\text {st: }}: 0.31(0.20) \\
2^{\text {nd }}: 0.33(0.20) \\
3^{\text {rd: }}: 0.38(0.22) \\
4^{\text {th. }}: 0.39(0.22) \\
5^{\text {th: }}: 0.40(0.22) \\
\text { Significant } \\
\text { differences } \\
\text { Quintil F+V: } \\
1^{\text {st: }} 0.31(0.20) \\
2^{\text {nd }}: 0.35(0.21) \\
3^{\text {rd: }}: 0.37(0.23) \\
4^{\text {th. }}: 0.40(0.22) \\
5^{\text {th: }}: 0.39(0.22) \\
\text { Significant } \\
\text { differences }\end{array}$ & $\begin{array}{l}\text { Pearson } \\
\text { correlation } \\
\text { (adjustment } \\
\text { for dietary L } \\
\text { and Z). }\end{array}$ & $\begin{array}{l}r=0.13(\mathrm{MPOD} \text { and } \\
\text { servings } \mathrm{F}+\mathrm{V}) \\
r=0.16 \text { (MPOD and } \\
\mathrm{L}+\mathrm{Z}) \\
\text { MPOD was } 31 \% \\
\text { higher in the fifth than } \\
\text { in the first quintiles of } \\
\text { dietary } \mathrm{L}+\mathrm{Z} \text { intake. }\end{array}$ \\
\hline $\begin{array}{l}\text { Nolan et al, } \\
2007^{75}\end{array}$ & Ireland & $\begin{array}{l}828 \\
\text { Healthy } \\
20-60 y\end{array}$ & $\begin{array}{l}\text { FFQ } \\
\text { USDA database } \\
\text { and O'Neill et al } \\
2001 .^{76,77}\end{array}$ & Values not given & HFP & Not reported & $\begin{array}{l}\text { Pearson } \\
\text { correlation }\end{array}$ & $\begin{array}{l}r=0.198 \text { (with L) } \\
r=0.203 \text { (with Z) } \\
(\mathrm{p}<0.001)\end{array}$ \\
\hline
\end{tabular}




\begin{tabular}{|c|c|c|c|c|c|c|c|c|}
\hline $\begin{array}{l}\text { Wenzel et } \\
\mathrm{al}, 2007^{17}\end{array}$ & & $\begin{array}{l}50 \\
\text { Healthy } \\
26-70 y\end{array}$ & $\begin{array}{l}\text { FFQ } \\
\text { University of } \\
\text { Minnesota } \\
\text { Nutrition } \\
\text { Coordinating } \\
\text { Center nutrient } \\
\text { database }\end{array}$ & $\begin{array}{l}\mathrm{L}+\mathrm{Z}: \\
\mathrm{W}: 2.1(0.2) \\
\mathrm{M}: 1.5(0.1) \\
\text { Significant differences }\end{array}$ & $\begin{array}{l}\text { HFP } \\
\left(20^{\prime}, 30^{\prime},\right. \\
\left.60^{\prime}, 120^{\prime}\right)\end{array}$ & $\begin{array}{l}20^{\prime} \\
\text { W: } 0.45(0.03) \\
\text { M: } 0.41(0.02) \\
30^{\prime} \\
\text { W: } 0.37(0.03) \\
\text { M: } 0.32(0.02) \\
\text { 60' } \\
\text { W: } 0.25(0.02) \\
\text { M: } 0.23(0.02) \\
\text { 120' } \\
\text { W: } 0.12(0.02) \\
\text { M: } 0.08(0.01) \\
\text { NS differences }\end{array}$ & $\begin{array}{l}\text { Pearson } \\
\text { correlation }\end{array}$ & $\begin{array}{l}\text { Energy-adjusted } \mathrm{L}+\mathrm{Z} \\
\text { intake was related to } \\
\text { MPOD at all } 4 \text { loci } \\
(\mathrm{p}<.05): \\
20^{\prime}: \mathrm{r}=0.336 \\
30^{\prime}: \mathrm{r}=0.446 \\
60^{\prime}: \mathrm{r}=0.318 \\
120^{\prime}: \mathrm{r}=0.325\end{array}$ \\
\hline $\begin{array}{l}\text { Berrow et } \\
\text { al, } 2011^{16}\end{array}$ & UK & $\begin{array}{l}81 \\
18-83 y \\
\text { Healthy } \\
(18-48 y) \\
\text { Healthy } \\
(50-77 y) \\
\text { ARM } \\
(52-83 y)\end{array}$ & $\begin{array}{l}\text { 3-days dietary } \\
\text { record } \\
\text { USDA }^{77}\end{array}$ & $\begin{array}{l}\mathrm{L}+\mathrm{Z} \\
\mathrm{H}: 18-48 \mathrm{y}: \\
1317(1624) \\
\mathrm{H}: 50-77 \mathrm{y}: \\
1916(1506) \\
\text { ARM: } \\
1924 \text { (1054) } \\
\text { NS differences }\end{array}$ & HFP & $\begin{array}{l}\text { H:18-48y: } \\
0.36(0.15) \\
\text { H: } 50-77 y: \\
0.40(0.20) \\
\text { ARM: } \\
0.38(0.24) \\
\text { NS differences }\end{array}$ & Not assessed & \\
\hline
\end{tabular}




\begin{tabular}{|c|c|c|c|c|c|c|c|c|}
\hline $\begin{array}{l}\text { Kyle-Little } \\
\text { et al, } 2014^{62}\end{array}$ & & $\begin{array}{l}46 \\
\text { Healthy } \\
19-33 y\end{array}$ & $\begin{array}{l}\text { 7-day dietary } \\
\text { records. } \\
\text { (Scores: } 1 \text { to } 5 \text { ) / } \\
\text { Frequency } \\
\text { of consumption }\end{array}$ & Values not given & HFP & $\begin{array}{l}\text { Conversion } \\
\text { genotypes: } \\
\text { High triple } \\
\text { CMO1: } \\
0.49 \text { (0.2) } \\
\text { Low triple } \\
\text { BMCO1: } 0.54 \\
(0.2)\end{array}$ & Not specified & $\begin{array}{l}\text { Subjects with the } \\
\text { lowest dietary score } \\
\text { had a lower MPOD: } \\
0.30(0.21) \text { du, } \\
\text { compared to those } \\
\text { with the highest score, } \\
\text { MPOD: f } 0.55(0.13) \\
\text { du }\end{array}$ \\
\hline $\begin{array}{l}\text { Olmedilla- } \\
\text { Alonso et } \\
\text { al, } 2014^{6}\end{array}$ & Spain & $\begin{array}{l}108 \\
\text { Healthy } \\
20-35 y \\
45-65 y \\
\text { Women / } \\
\text { men }\end{array}$ & $\begin{array}{l}\text { three } 24 \mathrm{~h} \text { recall } \\
\text { Food database: } \\
\text { Beltrán et al., } \\
2012^{55,78}\end{array}$ & $\begin{array}{l}\text { Fruit } \\
\text { 20-35y: } \\
\text { 150 (120) [152] } \\
\text { 45-65y: } \\
289(213)[269] \\
\text { Vegetables } \\
\text { 20-35y: } \\
\text { 238.0(128.4)[231.0] } \\
45-65 y: \\
311.9(159.4)[290.7] \\
\text { L } \\
20-35 y: \\
904(1572)[339.2] \\
45-65 y: \\
1242(1579)[529]\end{array}$ & HFP & $\begin{array}{l}\text { 20-35y: } \\
0.37(0.14) \\
\text { 45-65y: } \\
0.33(0.16) \\
\text { Significant } \\
\text { differences }\end{array}$ & $\begin{array}{l}\text { Spearman } \\
\text { correlation } \\
\text { Linear } \\
\text { Regression }\end{array}$ & $\begin{array}{l}\text { rho: } \\
\text { 20-35y: NS } \\
\text { 45-65y: } \\
\text { Z: rho=0.230 } \\
\text { L: rho: NS } \\
\text { F: rho }=0.318 \\
\text { V: rho= } 0.255 \\
\text { F+V: rho= } 0.350 \\
\text { Total sample: } \\
\text { L density: rho= } \\
\text {-0.147 } \\
\text { F: rho }=0.350 \\
\text { F + V: rho= } 0.171 \\
\text { Linear regression: no } \\
\text { significant } \\
\text { relationship }\end{array}$ \\
\hline
\end{tabular}




\begin{tabular}{|c|c|c|c|c|c|c|c|c|}
\hline & & & & $\begin{array}{l}Z \\
20-35 y: \\
92(144)[33] \\
45-65 y: \\
99(137)[46] \\
\text { L+ Z } \\
20-35 y: \\
995(1705)[369] \\
45-65 y: \\
1341(1693)[679]\end{array}$ & & & & \\
\hline $\begin{array}{l}\text { Nagai et al., } \\
2015^{65}\end{array}$ & Japan & $\begin{array}{l}55 \\
\text { Healthy } \\
23-53 y\end{array}$ & $\begin{array}{l}\text { Self-registered } \\
\text { questionnaire } \\
\text { FCT not specified }\end{array}$ & $\begin{array}{l}\mathrm{L}(\mathrm{mg} / 1,000 \mathrm{kcal}): \\
0.85(0.86)\end{array}$ & HFP & $0.65(0.21)$ & $\begin{array}{l}\text { Multiple } \\
\text { linear } \\
\text { regression } \\
\text { model }\end{array}$ & $\begin{array}{l}\text { correlation coefficient } \\
0.304 ;(p=0.002)\end{array}$ \\
\hline $\begin{array}{l}\text { Ren et al., } \\
2015^{63}\end{array}$ & China & $\begin{array}{l}225 \\
\text { Healthy } \\
\text { Early ARM } \\
>45 y\end{array}$ & $\begin{array}{l}\text { FFQ } \\
\text { Frecuency of } \\
\text { consumption }\end{array}$ & $\begin{array}{l}\text { Intake data are not } \\
\text { given. Subjects } \\
\text { classified as } \\
\text { consumers / not } \\
\text { consumers of some } \\
\text { specific foods. }\end{array}$ & HFP & $0.48(0.18)$ & $\begin{array}{l}\text { t-test } \\
\text { Univariate } \\
\text { linear } \\
\text { regression }\end{array}$ & $\begin{array}{l}\text { Participants who ate } \\
\text { carrot every week } \\
\text { had higher MPOD } \\
\text { than those who did } \\
\text { not }(p=<0.001) \text {. } \\
\text { Participants using } \\
\text { corn oil as the main } \\
\text { edible oil had } \\
\text { significantly higher } \\
\text { MPOD levels than } \\
\text { those mainly using } \\
\text { peanut oil }(p=<0.05)\end{array}$ \\
\hline
\end{tabular}




\begin{tabular}{|c|c|c|c|c|c|c|c|c|}
\hline $\begin{array}{l}\text { Estévez- } \\
\text { Santiago et } \\
\text { al, } 2016^{21}\end{array}$ & Spain & $\begin{array}{l}108 \\
\text { Healthy } \\
20-35 y \\
45-65 y \\
\text { Women / } \\
\text { Men }\end{array}$ & $\begin{array}{l}\text { three } 24 \mathrm{~h} \text { recall } \\
\text { Food database: } \\
\text { Beltran et al., } \\
2012^{55,78}\end{array}$ & $\begin{array}{l}\text { L+Z from: } \\
\text { Fruit } \\
\text { 20-35y: } \\
\text { 32.6(36.7)[19.5] } \\
\text { 45-65y: } \\
\text { 74.3(70.3)[68.2] } \\
\text { Vegetables } \\
\text { 20-35y: } \\
\text { 902.5(1714.1)[264.3] } \\
\text { 45-65y: } \\
\text { 1258.4(1731.2)[399.9] } \\
\text { Carotenoids from } \\
\text { plant foods: } \\
\text { White/Yellow } \\
\text { 20-35y: } \\
\text { 182 (132) [149] } \\
\text { 45-65y: } \\
\text { 217 (165) [171] } \\
\text { Red/orange } \\
\text { 20-35y: } \\
\text { 134 (90) [130] } \\
\text { 45-65y: } \\
\text { 211 (164) [178] } \\
\text { Green } \\
\text { 20-35y: }\end{array}$ & HFP & $\begin{array}{l}\text { 20-35y: } \\
0.37(0.14) \\
\text { 45-65y: } \\
0.33(0.16) \\
\text { Significant } \\
\text { differences }\end{array}$ & $\begin{array}{l}\text { General } \\
\text { linear model } \\
\text { (GLM) } \\
\text { Factorial } \\
\text { analysis }\end{array}$ & $\begin{array}{l}\text { GLM analysis: } \\
\text { F intake explained } \\
9.2 \% \text { of the variance } \\
\text { in MPOD. } \\
\mathrm{L}+\mathrm{Z} \text { intake from } \\
\text { red/orange foods: } \mathrm{L} \\
\text { explains } 12.7 \% \text { of the } \\
\text { variance in MPOD } \\
\text { and Z explains } 8.4 \% \text {. } \\
\text { Factorial analysis: } \\
\text { MPOD is related to } \\
\mathrm{L}+\mathrm{Z} \text { intake from F } \\
(0.264, \mathrm{P}=.003) \\
\text { MPOD is related to } \\
\text { the } \mathrm{L}+\mathrm{Z} \text { intake from } \\
\text { red/orange foods } \\
(0.320, p=.000) \text { and } \\
\text { to the intake from } \\
\text { white/yellowish foods } \\
(0.217, p=0.12) \text {. }\end{array}$ \\
\hline
\end{tabular}




\begin{tabular}{|c|c|c|c|c|c|c|c|c|}
\hline & & & & $\begin{array}{l}777(1689)[133] \\
45-65 y: \\
1090(1718)[241]\end{array}$ & & & & \\
\hline $\begin{array}{l}\text { Alassane et } \\
\text { al., } 2016^{67}\end{array}$ & France & $\begin{array}{l}443 \\
\text { Healthy } \\
>75 y\end{array}$ & $\begin{array}{l}\text { Validated FFQ } \\
\text { FCT not specified }\end{array}$ & Values not given & $\begin{array}{l}\text { Two- } \\
\text { wavelength } \\
\text { autofluoresc } \\
\text { ence } \\
\text { technique }\end{array}$ & $\begin{array}{l}0.5^{\circ}: 0.57(0.25) \\
1^{\circ}: 0.49(0.21) \\
2^{\circ}: 0.31(0.14) \\
6^{\circ}: 0.07(0.03)\end{array}$ & $\begin{array}{l}\text { Pearson or } \\
\text { Spearman } \\
\text { correlations }\end{array}$ & No association \\
\hline $\begin{array}{l}\text { She et al., } \\
2016^{64}\end{array}$ & China & $\begin{array}{l}435 \\
\text { - No diabetes } \\
\text { (NDM) } \\
\text { - Diabetes \& } \\
\text { no } \\
\text { retinopathy } \\
\text { (DMNR) } \\
\text { - Diabetes \& } \\
\text { retinopathy } \\
\text { (DMR) }\end{array}$ & $\begin{array}{l}\text { FFQ } \\
\text { Sommerburg et } \\
\text { al.,1998 }{ }^{79}\end{array}$ & $\begin{array}{l}\text { Intake at least one } \\
\text { time every week } \\
\text { within the latest } \\
\text { month. } \\
\text { Chinese wolfberry: } \\
\text { Healthy (H): } \\
63 \text { (28.8) } \\
\text { DMNR: } 40(29.9) \\
\text { DMR: } 20 \text { (41.7) } \\
\text { Green vegetables: }\end{array}$ & HFP & $\begin{array}{l}\text { Healthy: } 0.49 \\
(0.17) \\
\text { DMNR: } 0.45 \\
(0.21) \\
\text { DMR: } 0.49(0.21) \\
\text { NS differences }\end{array}$ & $\begin{array}{l}\text { Generalized } \\
\text { estimating } \\
\text { equations } \\
\text { model }\end{array}$ & $\begin{array}{l}\text { Intake of Chinese } \\
\text { wolfberry }(\mathrm{E}=0.0345 \text {, } \\
\mathrm{p}=0.01) \text { and green } \\
\text { vegetables } \\
(\mathrm{E}=0.0596,<0.001) \\
\text { were positively } \\
\text { associated with } \\
\text { MPOD. }\end{array}$ \\
\hline
\end{tabular}




\begin{tabular}{|c|c|c|c|c|c|c|c|c|}
\hline & & $>45 y$ & & $\begin{array}{l}\text { H:174 (79.5) } \\
\text { DNR: } 122(91) \\
\text { DWR:47 (98) } \\
\text { Carrots: } \\
\text { H: } 122(55.7) \\
\text { DNR: } 81(60.4) \\
\text { DWR: } 29(60.4) \\
\text { Significant differences }\end{array}$ & & & & \\
\hline $\begin{array}{l}\text { Khan et al, } \\
2018^{66}\end{array}$ & USA & $\begin{array}{l}114 \\
\text { Healthy } \\
25-45 y\end{array}$ & $\begin{array}{l}\text { 7-day diet records } \\
\text { University of } \\
\text { Minnesota } \\
\text { Nutrition } \\
\text { Coordinating } \\
\text { Center nutrient } \\
\text { database }\end{array}$ & $\begin{array}{l}\mathrm{L}+\mathrm{Z} \\
2320(3503)\end{array}$ & HFP & $0.46(0.21)$ & $\begin{array}{l}\text { Pearson } \\
\text { correlations }\end{array}$ & $r=0.06(p=0.52)$ \\
\hline
\end{tabular}

FFQ: food frequency questionnaire; SFFQ: semiquantitative food frequency questionnaire

$\mathrm{W}$ : women, M: men

HFP: heterochromatic flicker photometry.

$r$ : Pearson correlation coefficient; $r h o=$ Spearman correlation coefficient 


\section{Legends}

Figure 1 Correlation between MPOD (du) and fruit and vegetable intake (g) in subjects 20-35 years old (circle and dotted line) and 45-65 years old (square and solid line) groups. From ref. 6 (Olmedilla-Alonso et al., 2014).

Figure 2. Correlation matrix for MPOD, lutein plus zeaxanthin serum concentration and lutein plus zeaxanthin intake from the three major contributors to their dietary intake in subjects 45-65 y. MPOD is related to the lutein plus zeaxanthin intake from fruits, but independent of that from vegetables and eggs. From reference 21 (Estévez-Santiago et al., 2016).

Figure 3. Factor analysis loading plot for MPOD, lutein plus zeaxanthin intakes from plant foods grouped according to their color and lutein plus zeaxanthin serum concentrations in healthy subjects $45-65 y$. MPOD is related to the lutein plus zeaxanthin intake from red/orange plant foods.

From reference 21 (Estévez-Santiago et al., 2016)

Table 1. Lutein and zeaxanthin intakes fom fruits and vegetables and from the overall diet [mean \pm SD, (median)] and the MPOD in a group of healthy subjects. From references 6, 21 (Olmedilla-Alonso et al., 2014, Estévez-Santiago et al., 2016)

Table 2. Summary of studies investigating the relationship between MPOD and the intake of lutein and zeaxanthin. 


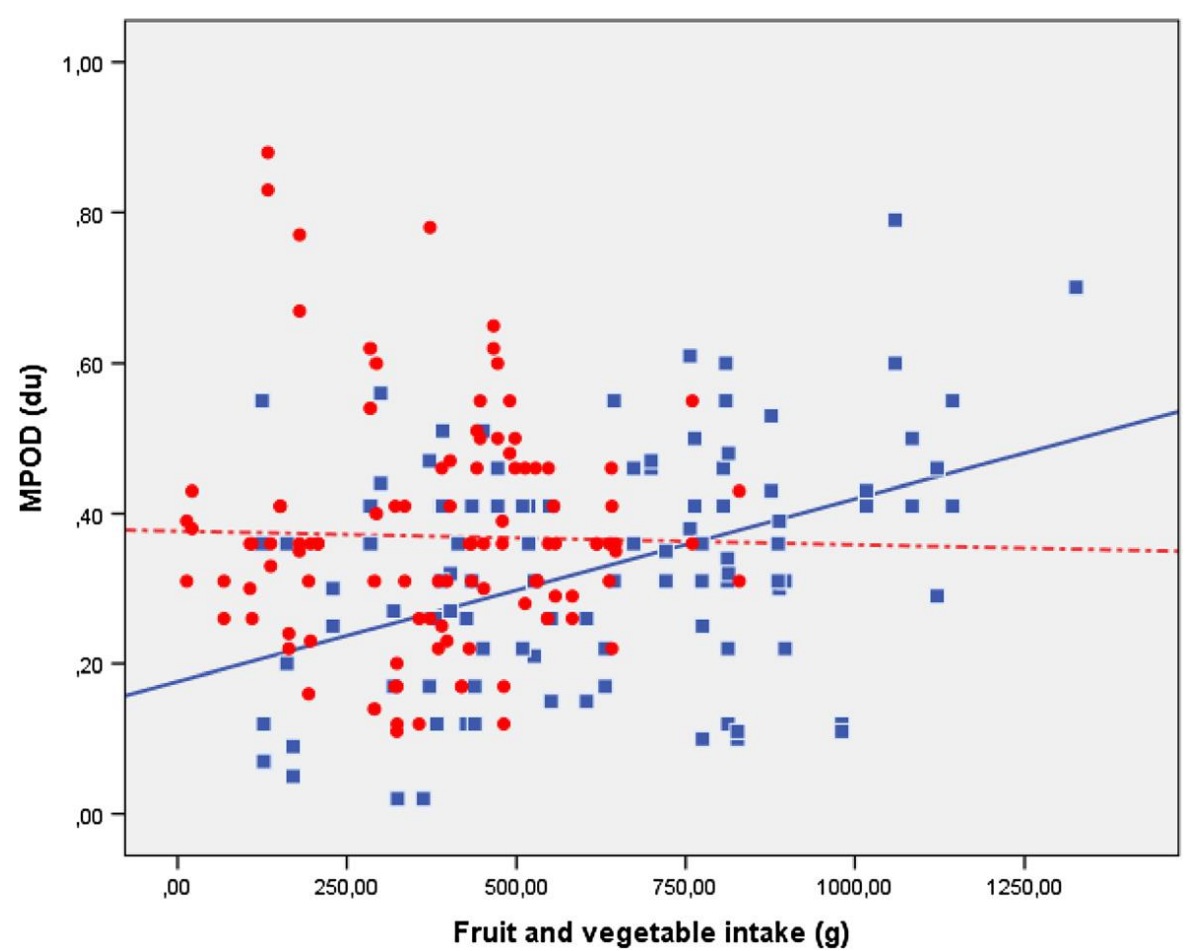

Figure 1 


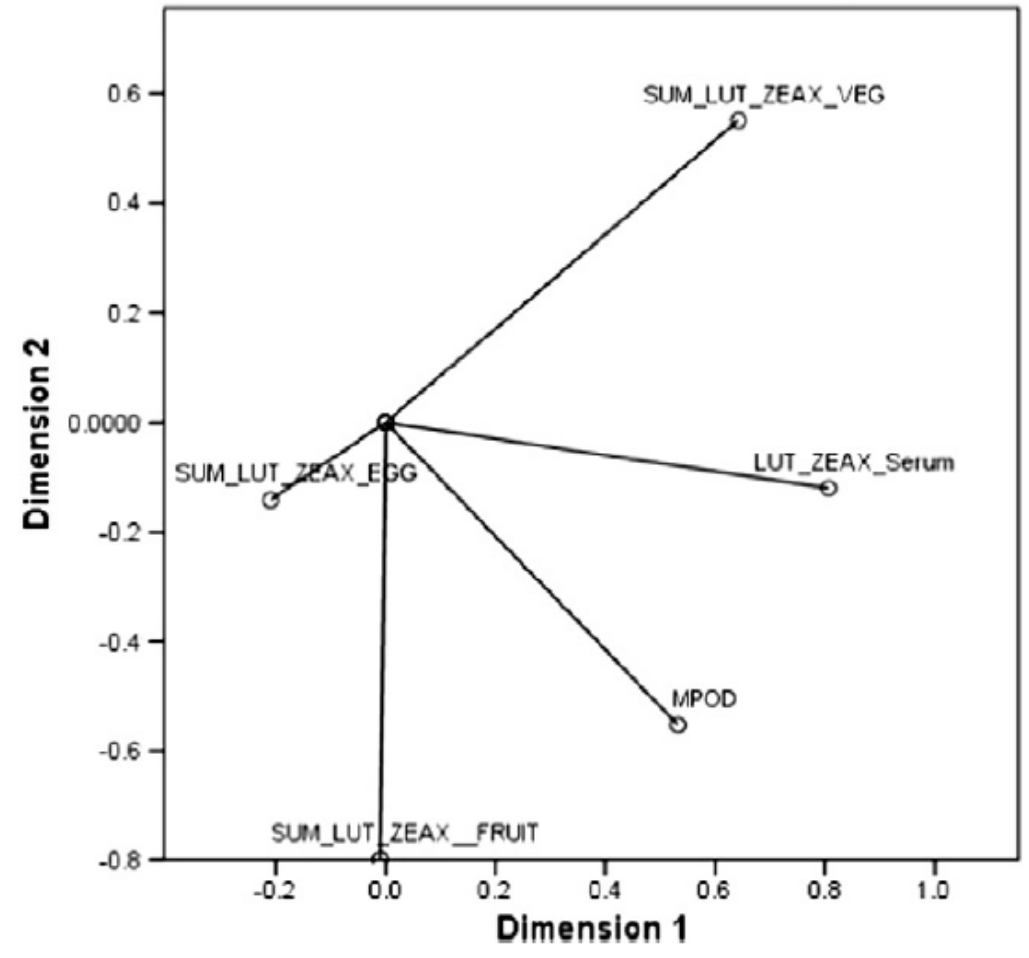

Figure 2 


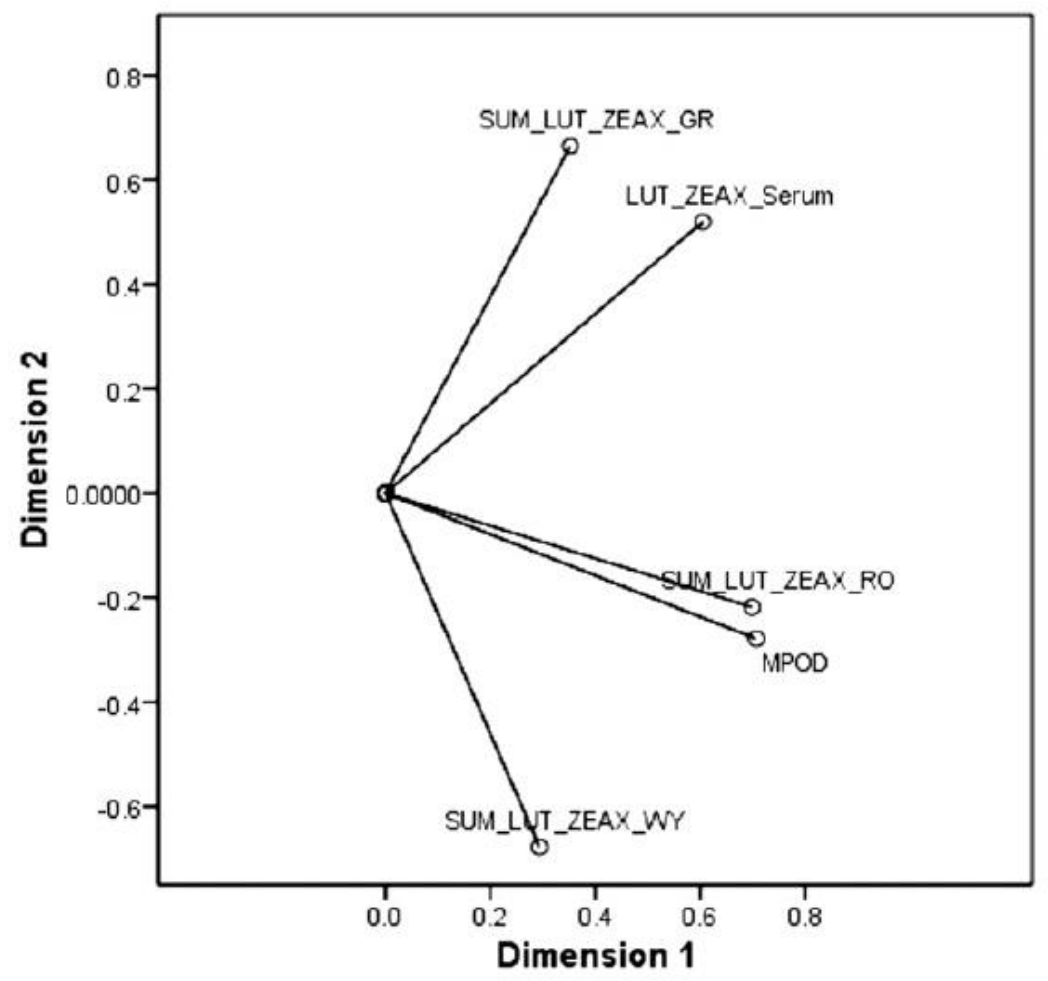

Figure 3 